\title{
DETERMINANT FATIGUE PADA PASIEN ESRD YANG MENJALANI HEMODIALISIS
}

\author{
Fitri Amelia ${ }^{1}$,Kiki Hardiansyah Safitri ${ }^{2}$, Suwanto $^{3}$ \\ ${ }^{1}$ Program Studi IImu Keperawatan ITKES Wiyata Husada Samarinda, JI. Kadrie Oening \\ No.77, Samarinda, Kalimantan Timur. \\ e-mail: ameliafitri0109@gmail.com \\ ${ }^{2}$ Program Studi IImu Keperawatan ITKES Wiyata Husada Samarinda, JI. Kadrie Oening \\ No.77, Samarinda, Kalimantan Timur. \\ e-mail: kikihardiansyahs@stikeswhs.ac.id \\ ${ }^{3}$ Program Studi IImu Keperawatan ITKES Wiyata Husada Samarinda, JI. Kadrie Oening \\ No.77, Samarinda, Kalimantan Timur. \\ e-mail: wanto71@ymail.com
}

\begin{abstract}
ABSTRAK
Latar Belakang: End Stage Renal Disease (ESRD) merupakan penyakit ginjal kronik stadium akhir yang perlu dilakukan terapi dialysis. Saat terapi hemodialisis dampak yang paling dominan dirasakan adalah fatigue. Faktor-faktor yang berhubungan dengan fatigue adalah kadar hemoglobin, lamanya menjalani hemodialisis, perubahan tekanan darah, dan Inter Dialysis Weight Gain (IDWG). Tujuan: Menganalisis faktor-faktor yang berkorelasi dengan fatigue pada pasien ESRD yang menjalani hemodialysis. Metode: Penelitian ini menggunakan korelasional dengan pendekatan cross-sectional. Jumlah responden sebanyak 30 dengan kriteria pasien telah menjalani hemodialisis kurang lebih 2 kali dan dalam keadaan sadar serta kooperatif. Pengukuran variabel dilakukan dengan pengukuran/observasi dan menggunkan kuesioner FACIT fatigue scale versi 4 secara online. Hasil: hasil penelitian ini didapatkan kadar hemoglobin nilai median 7,95 ( $\min 5,00$ max 13,50), lamanya menjalani hemodialisis median 14,00( $\min 2 \max 96)$, tekanan darah sistol mean 155,76 (SD = 26,11), diastol mean 79,93 (SD = 12,39), IDWG mean 2,45 (SD = 1,169), fatigue median 44,0 ( $\min 15 \max 50)$. Uji korelasi fatigue dengan kadar hemoglobin ( $p$ value $0,379, \quad r=-0,167$ ), lamanya menjalani hemodialisis ( $p$ value $0,007, r=-0,479$ ), tekanan darah sistol ( $p$ value $0,565, r=-0,109)$, diastol ( $p$ value $0,195, r=0,234)$, IDWG ( $p$ value $0,525, r=-0,121)$. Kesimpulan: Yang artinya adanya korelasi bermakna untuk lamanya menjalani hemodialisis dengan fatigue. Tidak ada korelasi bermakna antara kadar hemoglobin, tekanan darah, dan IDWG dengan fatigue.
\end{abstract}

Kata kunci: Faktor, Fatigue, ESRD, Hemodialisis

\section{PENDAHULUAN}

End Stage Renal Disease (ESRD) atau penyakit ginjal kronik stadium 5 merupakan penyakit ginjal kronik stadium akhir yang ditandai dengan laju filtrasi ginjal kurang dari $15 \mathrm{ml} /$ menit/1,73 m2. $E S R D$ disebabkan oleh fungsi renal yang menurun karena produk akhir metabolisme protein tertimbun dalam darah, sehingga mengakibatkan terjadinya uremia dan mempengaruhi seluruh sistem tubuh, semakin banyak timbunan produksi sampah maka gejala semakin berat sehingga ginjal mengalami kerusakan yang progresif dan fatal (Nursalam, 2011). 
Jurnal Keperawatan Wiyata

Volume 2, Nomor 1, Tahun 2021

ISSN 2774-4558 (Cetak)

ISSN 2774-9789 (Online)

Halaman 41-50

Prevalensi ESRD berdasarkan

diagnosis dokter di Indonesia sebesar 0,2 persen. Prevalensi tertinggi di Sulawesi Tengah sebesar $0,5 \%$, diikuti Aceh, Gorontalo, dan Sulawesi Utara masingmasing 0,4 \%. Sementara Nusa Tenggara Timur, Sulawesi Selatan, Lampung, Jawa Barat, Jawa Tengah, DI Yogyakarta, Jawa Timur masing-masing 0,3\% dan Bangka Belitung sebesar 0,1\% (Riskesdas, 2013).

Pada kondisi ESRD ini pasien wajib menjalani pengobatan atau terapi pengganti ginjal. Salah satu terapi pengganti ginjal yang sangat umum di Indonesia dan menjadi pilihan terbaik adalah hemodialisis (Rahayu, Fernandoz, \& Ramlis, 2018).

Pasien penyakit ginjal kronik yang menjalani hemodialisis, membutuhkan waktu sekitar 12-15 jam untuk dialisis setiap minggunya, atau paling sedikit 3-4 jam setiap kali melakukan hemodialisis. Kegiatan ini akan berlangsung terusmenerus sepanjang hidupnya. Terapi hemodialisis saat ini menjadi terapi utama dalam penanganan pasien gagal ginjal tahap akhir, terapi ini harus dijalani pasien seumur hidup yang tentu saja selain manfaatnya juga berdampak pada pasien $E S R D$. Selain itu dampak lain yang dirasakan paling dominan pada pasien $E S R D$ yang menjalani hemodialisis adalah fatigue (Suparti dkk, 2018).

Berdasarkan North American Nursing Diagnosis Association (NANDA, 2015-
2017), fatigue atau kelelahan didefinisikan sebagai keletihan terus menerus dan penurunan kapasitas untuk kerja fisik dan mental pada tingkatan yang lazim. . Fatigue (kelelahan) adalah perasaan subyektif yang tidak menyenangkan berupa kelelahan, kelemahan, dan penurunan energy dan merupakan keluhan tama pasien dialisis dengan prevalensi mencapai $60-97 \%$.Fatigue yang tidak teratasi dengan baik akan meningkatkan berbagai macam resiko seperti terganggunya fungsi fisik dalam melakukan aktivitas sehari-hari, perubahan hubungan dengan orang lain, isolasi sosial, perubahan fungsi kualitas hidup. Dampak lanjut fatigue akan menyebabkan kematian, gagal jantung, komplikasi akibat gagal jantung atau dirawat untuk pertamakalinya akibat gagal jantung selama menjalani terapi hemodialysis (Suparti dkk, 2018).

Faktor yang menyebabkan fatigue saat menjalani hemdialisis terjadi karna beberapa faktor. Faktor pertama kadar hemoglobin yang rendah memungkinkan terjadinya keluhan-keluhan utama dan penyerta pada pasien penyakit ginjal kronis diantaranya diantaranya sesak nafas, kelemahan fisik dan fatigue (Pitoyo \& Supriyitno, 2018). Faktor kedua fatigue adalah lamanya hemodialisis proses terapi hemodialisis yang membutuhkan waktu selama 5 jam, umumnya akan menimbulkan stres fisik pada pasien 
Jurnal Keperawatan Wiyata

Volume 2, Nomor 1, Tahun 2021

ISSN 2774-4558 (Cetak)

ISSN 2774-9789 (Online)

Halaman 41-50

setelah hemodialisis. Pasien akan

kelelahan yang mereka rasakan

merasakan fatigue, sakit kepala dan

dikarenakan lamanya melakukan cuci

keluar keringat dingin akibat tekanan darah dan rasa haus yang mereka darah yang menurun, sehubungan dengan rasakan dikaenakan pembatasan efek hemodialisis (Sulaiman et all, 2015).

Faktor ke tiga fatigue adalah perubahan tekanan darah, menurut Blake, dan Ing (2015), mengemukakan bahwa hipotensi intradialisis merupakan komplikasi yang paling sering dijumpai pada pasien hemodialisis yang kejsdiannya mencapai 20 sampai 33\%. Menyebabkan memunculnya gejala seperti perasaan tidak nyaman pada perut, otot terasa keram menguap mual, muntah, gelisah, pusing, kelelahan, dan kecemasan (Sahran, 2018).

Faktor keempat fatigue adalah Inter Dialysis Weight Gain (IDWG, IDWG merupakan peningkatan volume cairan yang dimanifestasikan dengan peningkatan berat badan sebagai dasar untuk mengetahui jumlah cairan yang masuk selama periode interdialitik (Bayhakki, Hasneli, 2017). Penambahan nilai IDWG yang terlalu tinggi dapat menimbulkan efek negatif terhadap tubuh diantaranya terjadi hipotensi, kram otot, sesak nafas, mual dan muntah, kelelahan (fatigue) (Moissl et al, 2013).

Berdasarkan studi fenomenologi yang didapatkan, pada pasien end stage renal disease di instalasi hemodialisis RSUD Abdul Wahab Sjahranie Samarinda, dari 4 responden 2 orang mengatakan bahwa pemenuhan cairan, 2 orang mengatakan karna kelelahan dirasakan karena hemoglobin yang turun membuat pasien sering lelah dan pusing ketika beraktivitas sehari-hari.

Melihat fenomena diatas maka perlu adanya penelitian untuk mengetahui sikap pasien terhadap fatigue. Peneliti mengangkat masalah tersebut sebagai penelitian dengan judul Faktor-Faktor Yang Berhubungan Dengan Fatigue pada Pasien ESRD yang Menjalani Hemodialisi Di RS Dirgahayu Samarinda.

\section{METODE}

Penelitian ini merupakan penelitian kuantitatif dengan metode penelitian Correlation yang menggunakan pendekatan cross sectional. Populasi pada penelitain ini adalah pasien end stage renal disease yang menjalani hemodialisis dengan jumlah responden sebanyak 30 dengan kriteria pasien telah menjalani hemodialisis kurang lebih 2 kali dan dalam keadaan sadar serta kooperatif Pengukuran variabel dilakukan dengan pengukuran/observasi dan menggunkan kuesioner FACIT fatigue scale versi 4 dalam bentuk google from.

\section{HASIL}

Penelitian ini menganalisis faktorfaktor yang berkorelasi dengan fatigue 
Jurnal Keperawatan Wiyata

Volume 2, Nomor 1, Tahun 2021

ISSN 2774-4558 (Cetak)

ISSN 2774-9789 (Online)

Halaman 41-50

pada pasien ESRD yang menjalani

Eritropoitin merupakan hormon

hemodialisis dirumah sakit Dirgahayu

Samarinda. Penelitian ini terdapat dua variabel yaitu penurunan kadar hemoglobin, lamanya menjalani hemodialisis, tekanan darah, dan IDWG sebagai variabel independen dengan fatigue sebagai variabel dependen.

Distribusi Karakteristik responden

\begin{tabular}{l|c|c|c}
\hline \multicolumn{1}{c|}{ Variabel } & $\boldsymbol{P}$ Value & $\mathbf{r}_{\mathbf{x y}}$ & Arah \\
\hline Hemoglobin/fatigue & 0,379 & $-0,167$ & Negatif \\
Lama menjalani & $0,007^{*}$ & $-0,479$ & Negaif \\
hemodialisis/fatigue & & & \\
Tekanan darah/fatigue & & & \\
Sistol & 0,565 & $-0,109$ & Negatif \\
Diastol & 0,195 & 0,243 & Positif \\
IDWG/fatigue & 0,525 & $-0,121$ & Negatif \\
\hline
\end{tabular}

\begin{tabular}{lccccc}
\hline \multicolumn{1}{c}{ Variabel } & Mean & Median & SD & Min & Max \\
\hline $\begin{array}{l}\text { Kadar } \\
\text { Hemoglobin }\end{array}$ & 8,05 & 7,95 & 1,68 & 5,00 & 13,50 \\
$\begin{array}{l}\text { Lama } \\
\text { menjalani }\end{array}$ & 20,83 & 14,00 & 22,65 & 2 & 96 \\
$\begin{array}{l}\text { hemodialisis } \\
\text { Tekanan }\end{array}$ & & & & & \\
darah & 155,77 & 159,50 & 26,11 & 103 & 228 \\
$\begin{array}{l}\text { a. Sistol } \\
\text { b. Diastol }\end{array}$ & 79,93 & 81,00 & 12,39 & 45 & 103 \\
IDWG & 2,45 & 2,50 & 1,169 & 0,50 & 5,00 \\
Fatigue & 40,53 & 44,00 & 9,94 & 15 & 50 \\
\hline
\end{tabular}

PEMBAHASAN

Korelasi antara kadar hemoglobin dengan fatigue

Hasil penelitian ini pada menunjukan bahwa 30 responden didapatkat berdasarkan karakteristik kadar hemoglobin menunjukan bahwa dari 30 responden yang paling dominan yang dimiliki dalah anemia sedang sebanyak 16 responden (53,3\%). Penurunan kadar $\mathrm{Hb}$ diakibatkan terganggunya produksi hormon eritropoetin.

\begin{tabular}{|c|c|c|}
\hline Kategori & Jumlah & $\begin{array}{c}\text { Presentase } \\
(\%)\end{array}$ \\
\hline \multicolumn{3}{|l|}{ Kadar hemoglobin } \\
\hline Tidak anemia ( $\geq 11 \mathrm{gr}$ ) & 2 & 6,7 \\
\hline Anemia ringan (9-10 gr) & 5 & 16,7 \\
\hline Anemia sedang (7-8 gr) & 16 & 53,3 \\
\hline Anemia berat $(<7 \mathrm{gr})$ & 7 & 23,3 \\
\hline Total & 30 & 100 \\
\hline \multicolumn{3}{|l|}{$\begin{array}{l}\text { Lama menjalani } \\
\text { hemodialysis }\end{array}$} \\
\hline$<12$ bulan & 12 & 40,0 \\
\hline$\geq 12$ bulan & 18 & 60,0 \\
\hline Total & 30 & 100 \\
\hline \multicolumn{3}{|l|}{$\begin{array}{l}\text { Tekanan darah } \\
\text { Sistol }\end{array}$} \\
\hline Normal $(<120)$ & 3 & 10,0 \\
\hline Pra- hipertensi (120-139) & 4 & 13,3 \\
\hline $\begin{array}{l}\text { Hipertensi stage } 1 \text { (140- } \\
\text { 159) }\end{array}$ & 8 & 26,7 \\
\hline Hipertesi stage $2(>160)$ & 15 & 50,0 \\
\hline Total & 30 & 100 \\
\hline \multicolumn{3}{|l|}{ Disatol } \\
\hline Normal $(<80)$ & 14 & 46,7 \\
\hline Pra-hipetensi (80-89) & 12 & 40,0 \\
\hline Hipertensi stage 1 (90-99) & 1 & 3,3 \\
\hline Hipertensi stage $2(>100)$ & 3 & 10,0 \\
\hline Total & 30 & 100 \\
\hline \multicolumn{3}{|l|}{ IDWG } \\
\hline Ringan & 10 & 33,3 \\
\hline Sedang & 20 & 66,7 \\
\hline Total & 30 & 100 \\
\hline \multicolumn{3}{|l|}{ Fatigue } \\
\hline Tidak fatigue & 26 & 86,7 \\
\hline Fatigue & 4 & 13,3 \\
\hline Total & 30 & 100 \\
\hline koprotein yang & upakan & stimulan \\
\hline
\end{tabular}

metabolisme yang menghasilkan eritrosit.

Sintesis dominan eritropoitin terjadi pada sel di area interstitial peritubular ginjal, selain hati dan otak. Sel-sel ini memproduksi dan melepaskan eritropoetin ketika tingkat oksigen sangat rendah. Tingkat oksigen yang rendah dimungkinkan mengindikasikan anemia, dimana jumlah sel darah merah mengalami penurunan, sehingga hemoglobin yang membawa oksigen keseluruh tubuh juga mengalami penurunan (Mary LT, 2012). 
Jurnal Keperawatan Wiyata

Volume 2, Nomor 1, Tahun 2021

ISSN 2774-4558 (Cetak)

ISSN 2774-9789 (Online)

Halaman 41-50

Pada hasil analisis bivariat

menunjukan bahwa tidak terdapat huungan yang signifikan antara kadar hemoglobin dengan fatigue terhadap pasien ESRD yang menjalani hemodialisis dengan menggunakan uji sperman. Nilai $P$ value yang didapatkan 0,379 yang lebih besar dari nilai $n=0,05$ kekuatan korelasi (r) -0,167 yang artinya kekuatan korelasi sangan lemah, maka Ho diterima sehingga tidak ada korelasi bermakna antara kadar hemoglobin dengan fatigue pada pasien ESRD yang menjalani hemodialisis. Kesimpulan hasil hipotesisi terhadap korelasi sangat lemah antara kadar hemogloin dengan fatigue.

Penelitian ini sejalan dengan penelitian seperti Jhamb et all (2013) mengatakan bahwa secara teori fisiologi, hubungan antara hemoglobin dan fatigue diketahui dengan baik, akan tetapi pada penelitian ini hemoglobin tidak mempunyai korelasi dengan fatigue, hal ini bisa dikarenakan kadar hemoglobin yang mebdekati normal yaitu $11 \mathrm{mg} / \mathrm{dl}$.

\section{korelasi antara lama menjalani hemodialisis dengan fatigue pada pasien ESRD yang menalani hemodialisis \\ Hasil penelitian ini pada tabel 4.2 menunjukan bahwa 30 responden didapatkat laman menjalani hemodialisis yang lebih dominan adalah Berdasarkan karakteristik lamanya hemodialisis yang paling}

dominana $\geq 12$ bulan sebanyak 18 responden $(60,0 \%)$.

Pada hasil analisis bivariat menunjukan bahwa terdapat hubungan yang signifikan antara kadar hemoglobin dengan fatigue terhadap pasien ESRD yang menjalani hemodialisis dengan menggunakan uji sperman. Nilai $P$ value yang didapatkan 0,007 yang lebih kecil dari nilai $n=0,05$ kekuatan korelasi (r) $-0,479$ yang artinya kekuatan korelasi sedang, maka Ha diterima sehingga ada korelasi bermakna signifikan antara lamanya menjalani hemodialisis dengan fatigue pada pasien ESRD yang menjalani hemodialisis. Kesimpulan hasil hipotesisi terhadap peluang a antara lama menjalani hemodialisis dengan fatigue dengan bentuk hubungan negatif.

Hemodialisis merupakan suatu terapi yang dilakukan 2-3 kali seminggu dengan lama waktu 4-5 jam, yang bertujuan untuk mengeluarkan sisa-sisa metabolisme protein dan mengoreksi gangguan keseimbangan cairan dan elektrolit. Proses terapi hemodialisis yang membutuhkan waktu selama 5 jam, umumnya akan menimbulkan stres fisik pada pasien setelah hemodialisis. Pasien akan merasakan kelelahan, sakit kepala dan keluar keringat dingin akibat tekanan darah yang menurun, sehubungan dengan efek hemodialisis. 
Penelitian ini sejalan dengan

penelitian Darmawan et al, (2019)

menyatakan bahwa lama menjalani hemodilaisis berhubungan dengan fatigue, yang mayoritas responden menjalani hemodialisis dalam waktu (> 24 bulan). Sesuai dengang penelitian Asiti (2014) dan Dewi (2015) menyatakan pasien yang menjalani hemodialisis paling banyak $>24$ bulan.

Rustina (2012) menyatakan responden yang telah lama menjalani terapi hemodialisis cenderung memiliki tingkat cemas lebih rendah dibandingkan dengan responden yang baru menjalani hemodialisis, hal ini disebabkan karena dengan lamanya seseorang menjalani hemodialisis, maka seseorang akan lebih adaptif dengan tindakan dialisis. Pasien yang sudah lama menjalani terapi hemodialisis kemungkinan sudah dalam fase penerimaan.

\section{korelasi antara tekanan darah dengan fatigue pada pasien ESRD yang menalani hemodialysis}

Hasil penelitian ini pada tabel 4.2 menunjukan bahwa 30 responden didapatkat tekanan darah sistolyang paling dominan hipertensi stage 2 sebanyak 18 responden (60,0\%). Hasil tersebut menunjukan bahwa. Dan hasil unvariat menunjukan bahwa 30 responden didapatkan tekanan darah diastol yang paling dominan diastol normal sebanyak 14 responden $(46,7 \%)$.

Pada hasil analisis bivariat menunjukan bahwa tidak terdapat hubungan yang signifikan antara tekanan darah sistol dan diastol dengan fatigue terhdap pasien ESRD yang menjalani hemodialisis dengan menggunakan uji pearson. Nilai sistol $P$ value yang didapatkan $=0,565$ yang lebih besar dari nilai $n=0,05$ kekuatan korelasi ( $r$ ) -0,109 yang artinya kekuatan korelasi sangat lemah. Nilai diastol $p$ value $=0,195$ yang lebih besar dari nilai $n=0,05$ kekuatan korelasi $(r)$ 0,243, maka Ho diterima sehingga tidak ada korelasi bemakna antara tekanan darah dengan fatigue pada pasien ESRD yang menjalani hemodialisis. Kesimpulan hasil hipotesisi terhadap peluang sangat lemah antara tekanan darah dengan fatigue dengan bentuk hubungan negatif.

Tekanan Fatigue juga lebih sering dirasakan bila pasien mengalami hipotensi intradialisis. Hipotensi intradialisis akan menyebabkan gangguan perfusi jaringan (serebral, renal, miokard, perier). Saat aliran tekana darah terlalu renda, maka pengiriman nurtisi dan oksigen selru tubuh berkurang, sehingga menyebabkan kelelahan, kerusakan organ hingga kematian. Kejadian 
tersering hipotensi intradiaisis adalah pada 2 jam pertama sesi hemodialisis (Armiyati, 2012).

Penelitian ini sejalan dengan penelitian Mesaroh et al (2020) menyatakan bahwa tidak ada hubungan antara riwayat penyakit degan fatigue. Riwayat penyakit berdasarkan Renal Registy (IRR) tahun 2012, riwayat penyaki salah satunya adalah hipertensi 24\%. Hal tersebut sesuai dengan hasil penelitian (Sulistini et al., 2012), bahwa tidak ada hubungan antara riwayat penyakit dengan terjadinya fatigue $(P=0,42)$. Hasil penelitian ini menunjukan

korelasi antara IDWG dengan
fatigue pada pasien ESRD yang
menalani hemodialysis
Hasil penelitian ini menunjukan
pada tabel 4.2 menunjukan bahwa 30 responden didapatkat IDWG yang lebih dominan. Berdasarkan karakteristik IWDG yang paling dominana adalah kenaikan sedang sebanyak 20 responden $(66,7 \%)$.

Pada hasil analisis bivariat menunjukan baha tidak terdapat hubungan yang signifikan antara IDWG dengan fatigue terhadap pasien ESRD yang menjalani hemodialisis dengan menggunakan uji pearson. Nilai $P$ value yang didapatkan 0,525 yang lebih besar dari nilai $n=0,05$ kekuatan korelasi ( $r$ ) $-0,121$ yang artinya kekuatan korelasi sangan lemah, maka
Ha diterima sehingga tidak ada korelasi bermakna signifikan antara IDWG dengan fatigue pada pasien ESRD yang menjalani hemodialisis. Kesimpulan hasil hipotesisi terhadap peluang sangat lemah antara IDWG dengan fatigue dengan bentuk hubungan negatif.

Intra Dialisis Weight Gain (IDWG) adalah pertambahan berat badan klien diantara dua waktu dialisis (perkumpulan Nefrologi Indonesia, 2016). Penambahan ini dihitung berdasarkan berat badan kering (dry wight) klien, yaitu berat badan post dialysisi setelah sebagaian besar cairan dibuang melalui proses UF (ultrafiltrasi). Peningkatan berat badan selama periode interdialitik dapat mengakibatkan berbagai macanm komplikasi. Komplikasi ini sangat mebahayakan pasien karena pada saat periode interdialitik pasien berada di rumah tanpa pengawasan dari petugas kesehatan (Perkumpulan Nefrologi Indonesia, 2016).

Pembatasan asupan cairan serta makanan dalam menjalani terapi dialisis sering menghilangkan semangat hidup pasien serta keluarganya sehingga dapat mempengaruhi pada kehidupan fi sik maupun psikologis pasien. Hal tersebut akan dapat memberikan dampak dan mempengaruhi serta menurunkan 
Jurnal Keperawatan Wiyata

Volume 2, Nomor 1, Tahun 2021

ISSN 2774-4558 (Cetak)

ISSN 2774-9789 (Online)

Halaman 41-50

kualitas hidup pasien hemodialisis

sehingga menyebabkan perubahan

pada kemampuan untuk melaksanakan

fungsi kehidupan sehari-hari dan

membutuhkan peningkatan komplesitas

penanganan pasien besar (Wahyuni et al, 2014).

Menurut Lindberg (2010) IDWG yang harus dicapai oleh pasien hemodialisis berada dalam kisaran $2,5 \%$ sampai $3,5 \%$. Upaya dalam mencapai target tersebut dapat dilakukan dengan bertumpu pada beberapa prinsip yaitu membatasi asupan diet tinggi natrium, menyesuaikan konsentrasi natrium dialisat sesuai kebutuhan masingmasing pasien, manajemen berat badan kering, dan memberikan durasi hemodialisis yang adekuat (Agarwal dkk,2014).

\section{KESIMPULLAN}

1. Hemoglobin nilai median 7,95 (min 5,00 max 13,50), lamanya menjalani hemodialisis median $14,00(\min 2 \max$ 96), tekanan darah sistol mean 155,76 $(S D=26,11)$, diastol mean 79,93 (SD = 12,39), IDWG mean 2,45 (SD = 1,169), fatigue median 44,0 ( $\min 15 \max 50)$.

2. Lamanya menjalani hemodialisis memiliki korelasi bermakna dengan fatigue dengan kekuatan korelasi sedang dengan bentuk arah negatif diamana semakin lama menjalani hemodialisis semakin rendah fatigue.
3. Kadar hemoglobin, tekana darah, IDWG memiliki korelasi yang tidak bermakna dengan fatigue dengan kekuatan korelasi sangat lemah dengan bentuk arah negatif

\section{DAFTAR PUSTAKA}

Astiti, A. (2014). Analisis faktor-faktor yang berhubungan dengan depresi pada pasien gagal ginjal kronik yang menjalani hemodialisis di rsud panembahan senopati bantul. Jogjakarta: Univesitas Muhammadyah.

Bayhakki, Yesi Hasneli (2017). Hubungan Lama Menjalani Hemodialisis dengan Inter-Dialytic Weight Gain (IDWG) pada Pasien Hemodialisis. JKP Volume 5 Nomor 3.

Darmawan, P. E., Nurhesti, P. O. Y., Surdana, I. K. 2019. HUBUNGAN MENJALANI HEMODIALISIS DENGAN FATIGUE PADA PASIEN ESRD KIDNEY DISEASE. Community of Publishing In Nursing (COPING).

Dewi, S. P. (2015). Hubungan Lamanya Hemodialisa Dengan Kualitas Hidup Pasien Gagal Ginjal Di Rs Pku Muhammadiyah Yogyakarta. Skripsi Tidak Dipublikasikan. Yogyakarta: Program Studi IImu Keperawatan Sekolah Tinggi Ilmu Kesehatan 'Aisyiyah Yogyakarta.

Indonesian, P., Registry, R., Renal, I., Indonesia, P. N., Kesehatan, D., 

Indonesian, K., Registry, R., Irr, A. M., Registry, I. R., Ginjal, T., Memacu, P., Irr, P., Course, H. and Irr, L. (2017) '9th Report Of Indonesian Renal Registry 2016', pp. 1-46

Jhamb, M., Liang, K., Yabes, J., Steel, J. L., Dew, M. A., Shah, N. \& Unruh, M. (2013). Prevalence and Correlates of Fatigue in Chronic Kidney Disease and End-Stage Renal Disease: Are Sleep Disorders a Key to Understanding Fatigue? American Journal of Nephrology, 38, 489-495.

Lindberg, 2010, Excessive fluid Overload Among Haemodialysis Patient: Prevalence,Individual Characteristics And Self Regulation Fluid Intake, Acta, Universitatis Upsaliensis Uppsala, $9-73$

Mary L.T. 2012. Clinical Hematology. Lippincott Williams \& Wilkins. Philadelphia.

Moissl, U., Guillen, M.A., Wabel, P., Fontsere, N., Carrera, M., Campistol, J.M, Maduell, F. (2013). Bioimpedance Guided Fluid Management in Hemodialysis Patients. Clin J Am Soc Nephrol 8(9): 1575-1582. Diakses 3 Januari 2016 dari NANDA International.(2015), Nursing Diagnosis and Classification 2015- 2017, Wiley Blackwell, (2015).

Nursalam. (2014). Manajemen keperawatan aplikasi dalam praktik keperawatan profesional edisi 4. Jakarta : Salemba Medika

Rahayu, F., Fernandoz, T., \& Ramlis, R. (2018). Hubungan Frekuensi Hemodialisis dengan Tingkat Stres pada Pasien Gagal Ginjal Kronik yang Menjalani Hemodialisis. Jurnal Keperawatan Silampari. https://doi.org/10.31539/jks.v1i2.7

Sahran. 2018. Faktor-Faktor Yang Mepengaruhi Terjadinya Hipotensi Iterdialisis Pada Pasien Gagal Ginjal Terminal Ynag Menjalani Hemodialisis. Jurnal Media Keperawatan, volume 11, hlm 062101

Sulistini, R., Yetti, K., \& Hariyati, R. T. S. (2012). Faktor Faktor yang Mempengaruhi Fatigue Pada Pasien yang Menjalani Hemodialisis. Jurnal Keperawatan Indonesia, 15(2).

Suparti dkk, S. (2018). Hubungan Depresi dengan Fatigue pada Pasien Hemodialisis. Journal of Health Studies.

https://doi.org/10.31101/jhes.435

Wahyuni., Irawati, W., Indrayana, S. 2014.

Korelasi Penambahan Berat Badan Diantara Dua Waktu Dialisis Dengan Kualitas Hidup Pasien Menjalani Hemodialisa. Jurnal Ners Dan Kebidanan Indonesia. 